Article

\title{
Growth and Nutrient Removal Efficiency of Sweet Wormwood (Artemisia annua) in a Recirculating Aquaculture System for Nile Tilapia (Oreochromis niloticus)
}

\author{
Zipporah Gichana $^{1}$, Paul Meulenbroek ${ }^{1, *}$, Erick Ogello ${ }^{2}{ }^{\oplus}$, Silke Drexler ${ }^{1}$, \\ Werner Zollitsch ${ }^{3}$, David Liti ${ }^{4}$, Peter Akoll ${ }^{5}$ and Herwig Waidbacher ${ }^{1}$ \\ 1 Institute of Hydrobiology and Aquatic Ecosystem Management, University of Natural Resources and Life \\ Sciences, 1180 Vienna, Austria; zippmoraa@yahoo.co.uk (Z.G.); silke.drexler@boku.ac.at (S.D.); \\ herwig.waidbacher@boku.ac.at (H.W.) \\ 2 Department of Fisheries and Natural Resources, Maseno University, Private Bag, Maseno 40105, Kenya; \\ erick.ogello@gmail.com \\ 3 Division of Livestock Sciences, University of Natural Resources and Life Sciences (BOKU), 1180 Vienna, \\ Austria; werner.zollitsch@boku.ac.at \\ 4 Department of Biological Sciences, University of Eldoret, 1125, Eldoret 30100, Kenya; \\ davidmbevaliti@gmail.com \\ 5 Department of Zoology, Entomology and Fisheries Sciences, Makerere University, Kampala 7062, Uganda; \\ pakoll@cns.mk.ac.ug \\ * Correspondence: paul.meulenbroek@boku.ac.at
}

Received: 20 March 2019; Accepted: 23 April 2019; Published: 1 May 2019

check for updates

\begin{abstract}
The maintenance of optimal water quality for fish production is one of the major challenges in aquaculture. Aquaponic systems can improve the quality of water for fish by removing the undesirable wastes and in turn produce a second marketable crop. However, there is no information on the growth and nutrient removal capability of Artemisia annua in aquaponic systems. This study evaluated the effect of plant density on water quality, the growth of A. annua and Oreochromis niloticus in a small scale aquaponic system in Kenya. The aquaponic system consisted of three treatments representing different plant densities (D1: 48 plants $/ \mathrm{m}^{2}$, D2: 24 plants $/ \mathrm{m}^{2}$ and D3:0 plants $\left./ \mathrm{m}^{2}\right)$. The high plant density system contributed significantly $(p<0.05)$ to the removal of all nutrients. The removal efficiency of ammonia was significantly higher in D1 $(64.1 \pm 14.7 \%)$ than in D2 (44.5 $\pm 6.8 \%)$ and D3 (38.0 $\pm 12.1 \%)$. Nitrates and nitrites were inconsistent, whereas phosphorus increased gradually in all treatments. The productivity of plants was higher in D1 than D2. Fish growth rates were significantly higher in D1 $(0.35 \pm 0.03 \mathrm{~g} / \mathrm{d})$ and D2 $(0.32 \pm 0.02 \mathrm{~g} / \mathrm{d})$ than in D3 $(0.22 \pm 0.04 \mathrm{~g} / \mathrm{d})$. The results show that $A$. annua can be cultivated in aquaponic systems due to its nitrogen removal capabilities.
\end{abstract}

Keywords: aquaponics system; denitrification; Nile tilapia; nitrification; plant density

\section{Introduction}

Aquaculture accounts for almost half of the fish consumed globally. The industry increased its contribution to the global fish production from $25.7 \%$ in 2000 to $46.8 \%$ in the year 2016 [1]. There is a general agreement that aquaculture will be the only way to ensure that the increasing global demand for fish are met. The expansion of the aquaculture sector will probably provide a solution to the declining global capture fisheries [1-3]. However, common aquaculture production systems are not sustainable, require large volumes of freshwater and more land for expansion [4]. Aquaculture in most 
Sub-Saharan African countries including Kenya is mainly practiced in extensive and semi-intensive production systems [3,5]. With the increasing scarcity of freshwater resources due to climate change as well as competition from other industries and increased demand from the rapidly growing population, a business-as-usual approach may not be an option for the aquaculture sector $[2,3,6,7]$.

The existing production systems manage the accumulation of both solid and dissolved wastes through frequent renewal or exchange of water [8]. However, water exchange requires the supply of sufficient water from adjacent water bodies. Furthermore, the discharge of untreated aquaculture wastewater deteriorates water quality of the receiving aquatic environment and creates a risk for spreading diseases between different aquaculture production systems [9]. The above-mentioned constraints drive the need for new and sustainable ways that will increase fish production, minimize pressure on diminishing land and water resources and reduce the discharge of wastewater into adjacent water bodies [10]. There is need to adopt sustainable fish production systems such as recirculating aquaculture [10]. Recirculating aquaculture is a suitable alternative to conventional aquaculture due to minimal wastewater discharge as well as efficient use of land and water resources [11]. However, accumulation of nitrates in recirculating aquaculture systems require water exchange that is costly and undesirable [12]. Besides, stringent environmental regulations prompt for efficient nitrogen removal techniques that can reduce nitrate levels in the discharge water [13].

Aquaponics, which is the integration of hydroponics (production of plants without soil) with aquaculture is one of the most sustainable approaches that can reduce nutrient discharges from aquaculture and improve income from the production of both fish and crops [14]. In aquaponic systems, the nutrient-rich aquaculture wastewater provides nutrients for plants grown in the hydroponic subsystem [15]. Nutrient removal through plant and bacteria assimilation as well as microbial transformation processes reduce the dissolved nutrient concentrations which in turn improves overall water quality parameters for fish production $[9,14,16]$. This symbiotic relationship between fish, microbes and plants conserves water compared to conventional aquaculture systems [16]. Fish from aquaponic systems are grown in an environmentally sound manner without using antibiotics and the crops are free of pesticides and chemical residues [17]. Research and development of aquaponic systems is becoming more popular in industrialized countries such as Europe and USA with recent innovations of decoupled aquaponics that can maintain optimal conditions for fish, bacteria and plants $[9,18,19]$. However, the technology is still in its infancy stage in most African countries including Kenya, although the tropical climatic conditions are favorable for aquaponics [20].

Sustainable aquaponic production requires maintenance of optimal environmental conditions for optimal growth of fish, bacteria and plants [16]. But it is challenging to provide plants with optimum nutrient concentrations while avoiding any negative impacts on the fish and bacteria [21]. This is because, the concentration of nutrients available for plant growth in the aquaponic systems depend on fish production and fish feeding rates [14]. The appropriate fish feed ratio to plant growing area ranges from 15 to $180 \mathrm{~g}$ feed per square meter per day [22,23]. This ratio can be expressed in terms of volume. A study by [24] demonstrated that a $3 \mathrm{~m}^{3}$ hydroponic tank to $1 \mathrm{~m}^{3}$ fish production tank ratio was effective at reducing nutrients and corresponded with a high production of both fish and plants. But it is complex to determine the exact fish feed to plant ratio because fish and plant species have different nutritional requirements that are dependent on the growth stage and external factors such as system design [18].

Plant density is another factor that influences nutrient concentrations in aquaponic systems [14]. The number of plants per unit area is the most important factor to optimize yield in any production system. Too many or few plants per unit area can affect the quality of plants and reduce yields [25]. If the density of plants is too high, the concentration of nutrients in the aquaponic system decreases to levels that may be too low to sustain plant growth and result in nutrient deficiencies [26]. Low plant density may increase nutrient production while nutrient uptake remains the same. This can result in nutrient accumulation and eventually fish mortalities [26]. Therefore, selection of the required plant density that can make optimal use of available space, efficiently utilize nutrients and minimize 
inter- or intra-specific competition is necessary in aquaponic systems [25]. However, few studies have systematically investigated the effects of plant density on the performance of aquaponic systems. Moreover, the effect of plant density on growth and nutrient removal capacity of Artemisia annua in aquaponic systems is unknown. The objectives of this study were to evaluate: (1) the growth of A. annua in an aquaponic system, (2) the effect of plant density on the plant growth and water quality, and (3) the effect of plant density on the growth performance of Oreochromis niloticus in a small-scale aquaponic system in Kenya.

In this study, A. annua was selected because of its economic and technical values as a medicinal plant. A. annua is an annual shrub indigenous to China but can grow in a wide range of temperate and subtropical environments. It belongs to the plant family Asteraceae and is used as a tea infusion in traditional Chinese medicine to treat fever. It is also a key ingredient in artemisinin-based combination therapies (ACTs) effective in treating malaria which is endemic in Africa [27]. Besides, A. annua readily absorbs nutrients from the soil due to its abundant and dense lateral roots [28,29]. Other studies have shown that $A$. annua can be successfully grown in hydroponics, conditions similar to aquaponic systems. Moreover, studies focusing on the enhancement of artemisinin production reported that the use of organic fertilizers is one of the most effective approaches that can increase plant biomass and artemisinin content in A. annua [30].

\section{Materials and Methods}

\subsection{Experimental Design}

The study was conducted for 60 days from January to February 2018 in Aqualife fish farm, Machakos, Kenya. Nine aquaponic systems were constructed under a greenhouse to provide uniform conditions for fish and plant growth. Each system consisted of three $500 \mathrm{~L}$ circular fish tanks and a $0.1125 \mathrm{~m}^{3}$ rectangular hydroponic unit (Figure 1). A $210 \mathrm{~L}$ plastic barrel filled with sand of different sizes was used for solid removal and a biofilter was constructed from the same plastic barrel and filled with pumice stones (biofilter media). The media were initially rinsed in clean water and sundried. Fish were stocked in tanks prior to the start of the experiment to allow bacteria to naturally colonize the biofilter substrates [31]. Effluent water from fish tanks flowed by gravity to the sand filter where a centrifugal pump (0.5 HP, 8000 L/hr 370 W, Davis and Shirtliff, Nairobi, Kenya) was used to pump the water $(6 \pm 0.24 \mathrm{~L} / \mathrm{min})$ to the biological filter. The filtered water was then channeled by gravity to the hydroponic beds and pumped back to the fish tanks. The water flow into each hydroponic unit was adjusted to approximately $1.42 \pm 0.23 \mathrm{~L} / \mathrm{min}$ and no additional fertilizers or pesticides were used. An air pump ( $>0.03 \mathrm{Mpa}, 60 \mathrm{~L} / \mathrm{min}, \mathrm{V}-60$, Aqua Forte) was used to aerate the fish tanks and the biofiltration unit.

The outlet from each hydroponic unit was constructed as a bell siphon with auto-mechanical water out movement initiating the ebb under water pressure modified from [32]. Three treatments, D1, D2 and D3 representing 48 plants $/ \mathrm{m}^{2}, 24$ plants $/ \mathrm{m}^{2}$, and control with 0 plants $/ \mathrm{m}^{2}$ respectively were replicated three times in the hydroponic units. The average weight of O. niloticus at the start of the experiment was $112.9 \pm 6.7 \mathrm{~g}, 114.8 \pm 6.3 \mathrm{~g}$, and $110.5 \pm 7.3 \mathrm{~g}$ in D1, D2, and D3 density treatments respectively. The fish were broadcast fed twice a day (09:00h and 16:00h) to satiation with $30 \%$ crude protein diet during the study period. Sweet wormwood seeds were sown in four seedling trays (filled with loam soil) three weeks before the start of the experiment. Healthy seedlings with an average height of $4.51 \pm 0.43 \mathrm{~cm}, 5.37 \pm 1.87 \mathrm{~cm}$ and weight of $32.63 \pm 2.7 \mathrm{~g}, 14.33 \pm 0.85 \mathrm{~g}$ in D1 and D2 respectively were then transplanted into six hydroponic units. 


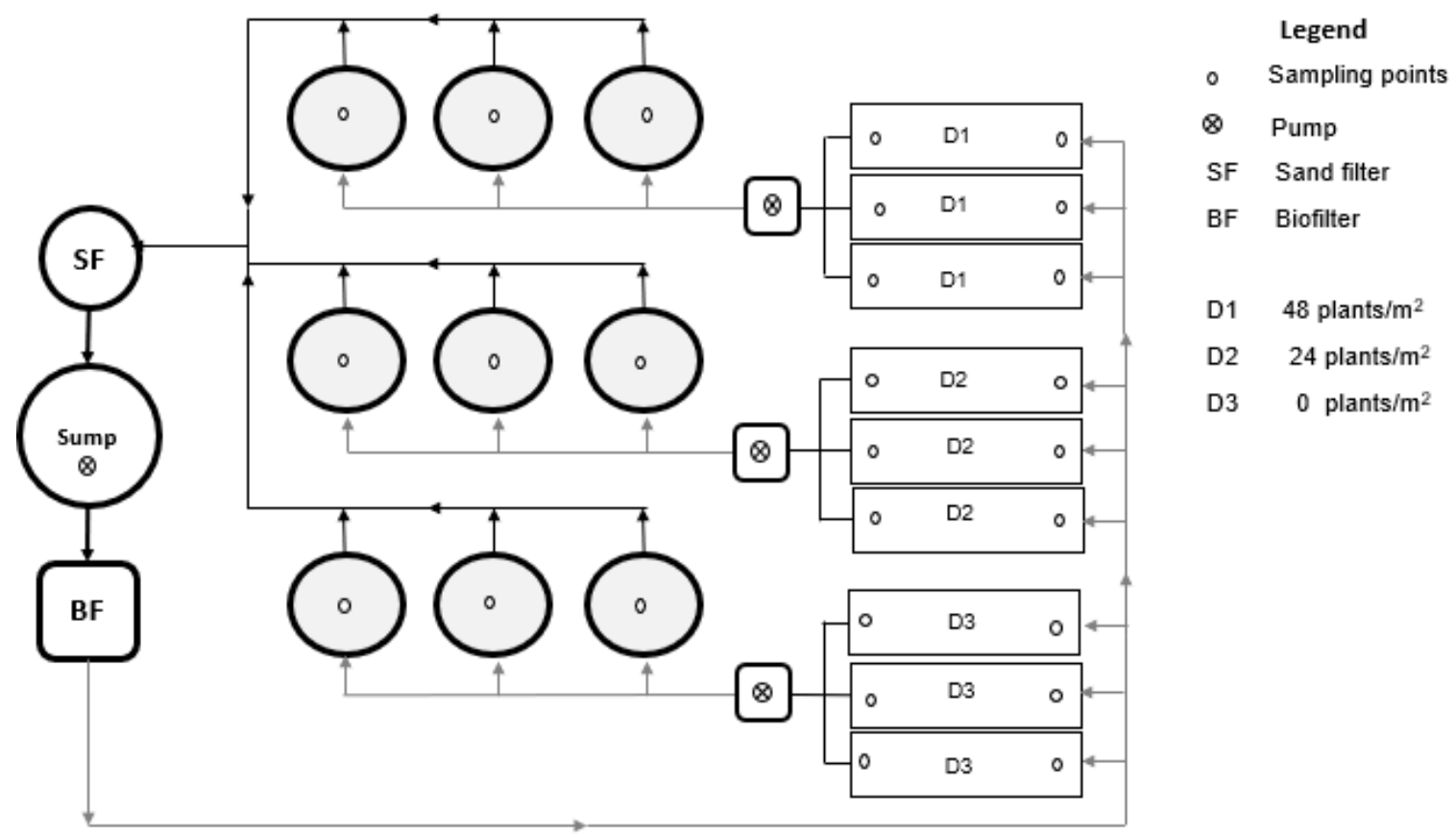

Figure 1. The experimental aquaponic system (not drawn to scale). Grey circles represent fish rearing tanks, rectangular boxes; hydroponic units, grey and black lines with arrows indicate the direction of water flow with grey representing inlet and black the outlet.

\subsection{Sampling and Analysis}

The temperature, $\mathrm{pH}$, dissolved oxygen and conductivity were measured twice daily in the fish tanks and hydroponic grow beds using Hach probes (HACH HQ40d Portable meter, Loveland, Colorado, USA). Water samples were collected in triplicate every two weeks from the fish tanks, inlet and outlet of the hydroponic units. On the day of collection, the samples were analysed for ammonium, nitrate, nitrite, phosphorus and alkalinity using benchtop Hanna multiparameter photometer (HI83200) based on Nessler, cadmium reduction, diazotization and ascorbic acid methods respectively [33]. The nutrient removal efficiencies of different plant densities in the grow beds were calculated using the following equation [14].

$$
\text { Removal efficiency }(\%)=\frac{C_{i}-C_{e}}{C_{i}} \times 100
$$

where $C_{i}=$ concentration of inlet and $C_{e}=$ concentration of outlet.

Fish were sampled biweekly and weighed to the nearest $0.1 \mathrm{~g}$ and the mean weight calculated. The performance of fish was evaluated using growth parameters such as weight gain, feed conversion ratio (FCR), survival rate in (\%) and specific growth rate (SGR). The growth parameters were calculated as below;

$$
\begin{aligned}
& \text { Weight gain }(\mathrm{g})=\text { Final weight }(\mathrm{g})-\text { initial weight }(\mathrm{g}) \\
& \qquad \begin{array}{c}
\text { FCR }=\frac{\text { Total weight of dry feed given }(\mathrm{g})}{\text { Total wet weight gain }(\mathrm{g})} \\
\text { Survival rate }=\frac{\mathrm{N}_{0}-\mathrm{N}_{\mathrm{t}}}{\mathrm{N}_{0}} \times 100 \\
\text { SGR }(\% / \text { day })=\left(\ln \mathrm{W}_{\mathrm{f}}-\ln \mathrm{l}_{\mathrm{i}}\right) / \mathrm{t} \times 100,
\end{array}
\end{aligned}
$$

where $W_{i}$ and $W_{f}$ are initial and final mean wet weight in $g$; $l n=$ natural logarithm; $t=$ time in days $N_{0}$ and $\mathrm{N}_{\mathrm{t}}$ are fish number at time 0 and at time $\mathrm{t}$.

The heights of the plants were measured biweekly while weights were measured at the start and end of the experiment. Final wet weights were measured after uprooting the whole plant from the 
hydroponic units. The fresh weights were then used to determine the relative growth rate (RGR), which was calculated as;

$$
\operatorname{RGR}=\left(\ln W_{2}-\ln W_{1}\right) /\left(t_{2}-t_{1}\right),
$$

where $W_{2}$ and $W_{1}$ are weights at time $t_{2}$ and $t_{1}, t_{2}$ and $t_{1}$ are initial and final periods and ln is the natural logarithm [34]. Plant yield $\left(\mathrm{kg} / \mathrm{m}^{2}\right)$ was calculated using the fresh weight obtained per square meter in each treatment.

\subsection{Data Analysis}

Data were presented as means and standard deviation (SD) of three replicates. Percentage data were subjected to arcsine transformation before statistical analyses. Normality and homogeneity of means were evaluated by Shapiro-Wilks and Levene tests respectively. The effect of plant density on water quality parameters, nutrient removal efficiency, and fish growth was tested using one-way analysis of variance (ANOVA) (version. 21.0, IBM Corp., Armonk, NY, USA). Two-way ANOVA was used to determine differences in nutrient concentrations between plant density treatments. Tukey post hoc test was performed when necessary to determine specific significant differences between the means. Statistical differences in growth of plants between D1 and D2 were determined using $t$-test. The relationship between fish growth and water quality variables was determined using multiple regression. Differences between the means were considered significant at $\alpha=0.05$. Statistical analysis was performed using the IBM SPSS Statistics for Windows (version. 21.0, IBM Corp., Armonk, NY, USA).

\section{Results}

\subsection{Water Quality Parameters}

The water temperature ranged from $22.4-24.2{ }^{\circ} \mathrm{C}$ and the $\mathrm{pH}$ was maintained between 7.68 and 8.17 in the fish tanks (Table 1). The conductivity fluctuated between 1312 and $1453 \mu \mathrm{S} / \mathrm{cm}$ and oxygen values ranged between 1.97 to $4.67 \mathrm{mg} / \mathrm{L}$. The maximum observed ammonia, nitrates, nitrites, and phosphorus concentrations were $3.7 \mathrm{mg} / \mathrm{L}, 3.6 \mathrm{mg} / \mathrm{L}, 1.04 \mathrm{mg} / \mathrm{L}$ and $4.1 \mathrm{mg} / \mathrm{L}$. However low ammonia levels were observed in fish tanks with higher plant densities and high levels of ammonia in the fish tank were observed in the control treatment (without plants). There were no significant differences in all water quality variables between the treatments $(p<0.05)$.

Table 1. Water quality parameters in fish tanks. All values are mean \pm standard deviation obtained from three replicates.

\begin{tabular}{cccccc}
\hline \multicolumn{5}{c}{ Treatments } \\
\hline Parameters & Units & D1 & D2 & D3 & $p$ \\
\hline Temperature & $\left({ }^{\circ} \mathrm{C}\right)$ & $23.34 \pm 0.53$ & $23.02 \pm 0.4$ & $23.13 \pm 0.44$ & 0.24 \\
pH & & $7.93 \pm 0.14$ & $7.97 \pm 0.17$ & $7.97 \pm 0.17$ & 0.77 \\
Dissolved oxygen & $(\mathrm{mg} / \mathrm{L})$ & $2.85 \pm 0.77$ & $3.29 \pm 0.82$ & $3.24 \pm 0.74$ & 0.33 \\
Conductivity & $(\mu \mathrm{H} / \mathrm{cm})$ & $1388.6 \pm 38.1$ & $1385.1 \pm 40.6$ & $1384.1 \pm 43.1$ & 0.96 \\
Ammonia & $(\mathrm{mg} / \mathrm{L})$ & $1.89 \pm 0.8$ & $2.16 \pm 0.87$ & $2.4 \pm 1.00$ & 0.39 \\
Nitrates & $(\mathrm{mg} / \mathrm{L})$ & $2.65 \pm 0.44$ & $2.74 \pm 0.47$ & $2.73 \pm 0.33$ & 0.88 \\
Nitrites & $(\mathrm{mg} / \mathrm{L})$ & $0.58 \pm 0.21$ & $0.55 \pm 0.27$ & $0.6 \pm 0.30$ & 0.88 \\
Phosphorus & $(\mathrm{mg} / \mathrm{L})$ & $2.88 \pm 0.78$ & $2.82 \pm 0.52$ & $2.65 \pm 0.46$ & 0.63 \\
\hline
\end{tabular}

Table 2 presents the descriptive statistics of water quality parameters in the hydroponic units. The mean values of temperature, $\mathrm{pH}$, dissolved oxygen and electrical conductivity were similar $(p>0.05)$. The water temperature, $\mathrm{pH}$ and dissolved oxygen fluctuated between 24.7 and $26.7{ }^{\circ} \mathrm{C}$, 6.9 to 8.0 and 1.5 to $3.4 \mathrm{mg} / \mathrm{L}$ respectively. The electrical conductivity was maintained at 1408.4 and $1467.4 \mathrm{\mu S} / \mathrm{cm}$ during the experimental period. 
Table 2. Physical-chemical water parameters in the hydroponic units (mean \pm SD) during the experimental period (60 days).

\begin{tabular}{cccccc}
\hline Parameter & Units & D1 & D2 & D3 & $p$ \\
\hline Temperature & $\left({ }^{\circ} \mathrm{C}\right)$ & $25.21 \pm 0.53$ & $25.53 \pm 0.53$ & $25.39 \pm 0.41$ & 0.3 \\
pH & & $7.89 \pm 0.13$ & $7.82 \pm 0.32$ & $7.92 \pm 0.08$ & 0.44 \\
Dissolved oxygen & $(\mathrm{mg} / \mathrm{L})$ & $2.66 \pm 0.35$ & $2.32 \pm 0.45$ & $2.35 \pm 0.36$ & 0.07 \\
Electrical conductivity & $(\mu \mathrm{S} / \mathrm{cm})$ & $1425.1 \pm 15.8$ & $1432.7 \pm 19.2$ & $1430.0 \pm 19.6$ & 0.59 \\
\hline
\end{tabular}

\subsubsection{Nutrient Removal}

In general, ammonia, nitrate and nitrite concentrations were relatively high at the start of the experiment except for phosphorus (Figure 2). Ammonia concentration was high at the start of the experiment (week 2) but decreased with time and ranged between $0.27 \pm 0.15-1.37 \pm 0.12 \mathrm{mg} / \mathrm{L}$ in the high density (D1), $0.84 \pm 0.09-1.79 \pm 0.08 \mathrm{mg} / \mathrm{L}$ in the low density (D2) and $0.84 \pm 0.14-2.34 \pm 0.15 \mathrm{mg} / \mathrm{L}$ in the control system (D3). Nitrate and nitrite levels were inconsistent during the sampling period with high concentrations at week 2 . Phosphorus concentration increased gradually during the sampling period with high concentrations at week 8 in the three aquaponic treatments. Moreover, all the nutrient concentrations were significantly lower $(p<0.05)$ in D1 than in D2 and D3 treatments. There were significant $(p<0.05)$ interactions between plant densities and sampling days for all nutrient concentrations except phosphorus.
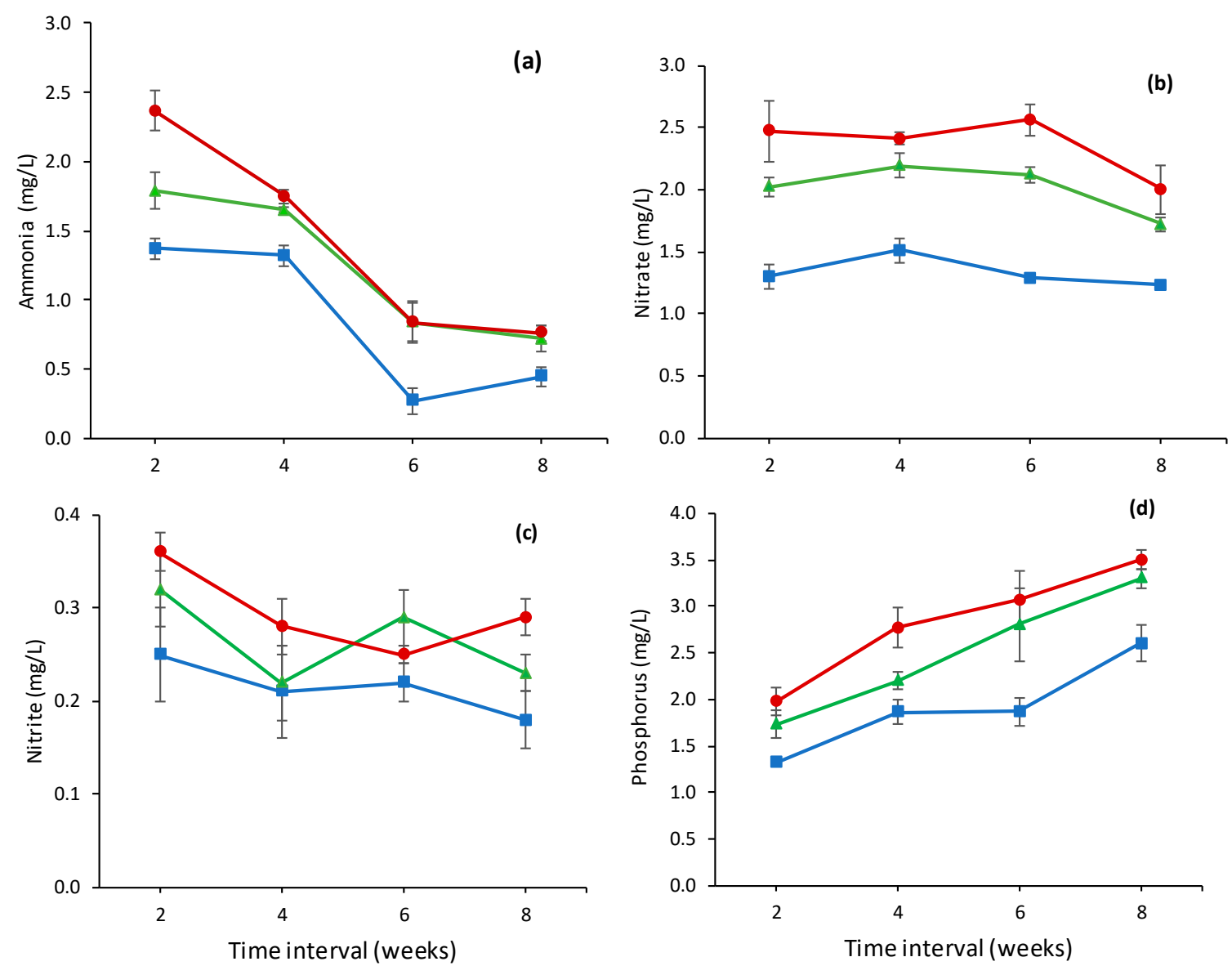

Figure 2. Trends in ammonia (a), nitrate (b), nitrite (c) and phosphorus (d) concentrations at the outlet from D1 (blue), D2 (green) and D3 (red) aquaponic units during the experiment. Points are means of three treatment replicates and error bars show standard deviation. 
The high plant density aquaponic system (D1) was effective in the removal of ammonia $(64.1 \pm 14.7 \%)$, nitrate $(57.5 \pm 4.2 \%)$, nitrite $(47.0 \pm 7.9 \%)$, and phosphorus $(46.6 \pm 9.5 \%)$. The calculated percentages of nutrient removal in D2 was $44.5 \pm 6.8 \%, 35.9 \pm 5.9 \%, 30.4 \pm 11.1 \%$ and $35.4 \pm 7.8 \%$ for ammonia, nitrate, nitrite and phosphorus respectively. The removal efficiency of ammonia (38.0 \pm 12.1$)$, nitrate $(24.8 \pm 9.2)$, nitrite $(21.5 \pm 11.9 \%)$ and phosphorus $(27.3 \pm 11.9 \%)$ was low in the control treatment (Figure 3). A significantly higher nutrient removal efficiency was observed in D1 $(p<0.05)$ than in D2 and D3. However, no significant differences were observed between D2 and D3 treatment except for nitrate removal $(p<0.05)$. The tested aquaponic systems were more effective in removing ammonia than nitrate, nitrite and phosphorus.
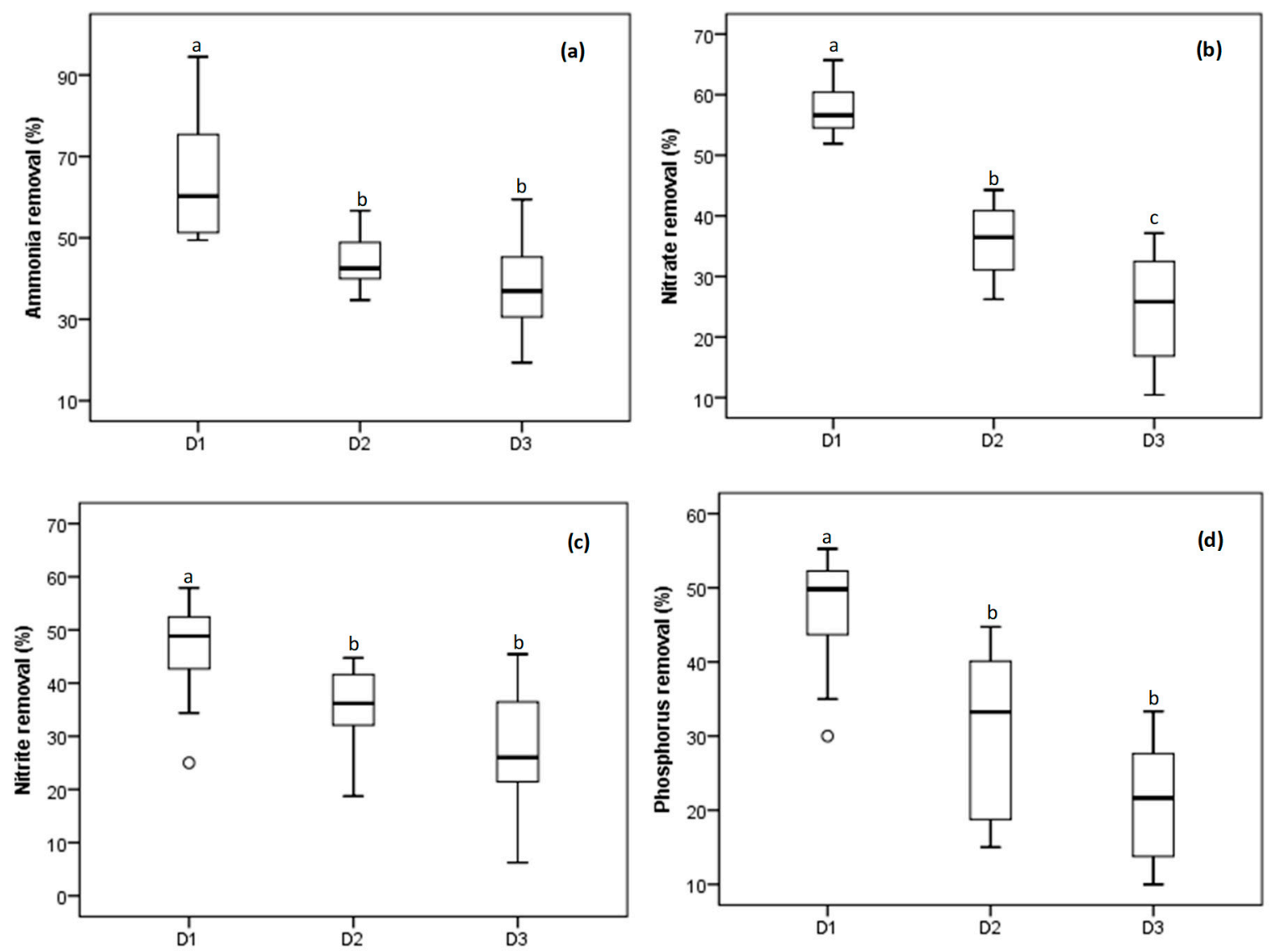

Figure 3. Ammonia (a), nitrate (b), nitrite (c), and phosphorus (d), removal efficiency (\%) of different plant densities in the aquaponic system. D1 represents 48 plants $/ \mathrm{m}^{2}, \mathrm{D} 2 ; 24$ plants $/ \mathrm{m}^{2}$ and D3; zero plants $/ \mathrm{m}^{2}$ (control). Different letters above boxplots indicate significant differences between density treatment (one-way ANOVA) $(p<0.05)$.

\subsubsection{Plant and Fish Growth}

Table 3 presents the growth performance of $A$. annua in D1 and D2 aquaponic systems. The relative growth rate ranged between 0.05 and $0.06 \mathrm{~g} / \mathrm{d}$ in the high density and low-density treatment. The final weight, weight gain and productivity of $A$. annua were significantly higher in the D1 treatment compared with D2 aquaponic treatment $(p<0.05)$. However, there was no significant $(p>0.05)$ difference in plant height and relative growth rate between the two plant densities. 
Table 3. Plant growth parameters in the aquaponic system. All values are mean \pm standard deviation obtained from three replicates. Different superscript letters $(a, b)$ within a row indicate statistically different mean values at $p<0.05 ; \mathrm{a}>\mathrm{b}$ ( $t$-test).

\begin{tabular}{cccc}
\hline Parameters & Units & D1 & D2 \\
\hline Initial height & $(\mathrm{cm})$ & $4.75 \pm 0.43^{\mathrm{a}}$ & $5.37 \pm 1.87^{\mathrm{a}}$ \\
Final height & $(\mathrm{cm})$ & $52.42 \pm 2.89^{\mathrm{a}}$ & $55.78 \pm 4.57^{\mathrm{a}}$ \\
Final weight (fresh weight) & $(\mathrm{g})$ & $423.3 \pm 25.2^{\mathrm{a}}$ & $223.3 \pm 25.2^{\mathrm{b}}$ \\
Weight gain (fresh weight) & $(\mathrm{g})$ & $390.7 \pm 26.8^{\mathrm{a}}$ & $209 \pm 24.3^{\mathrm{b}}$ \\
Yield (fresh weight) & $\left(\mathrm{kg} / \mathrm{m}^{2}\right)$ & $0.56 \pm 0.03^{\mathrm{a}}$ & $0.3 \pm 0.03^{\mathrm{b}}$ \\
Relative growth rate & $(\mathrm{g} / \mathrm{d})$ & $0.05 \pm 0.003^{\mathrm{a}}$ & $0.05 \pm 0.001^{\mathrm{a}}$ \\
\hline $\mathrm{a}, \mathrm{b}$ within a row indicate statistically different mean values at $p<0.05 ; \mathrm{a}>\mathrm{b}$ (t-test).
\end{tabular}

Results on growth performance of O. niloticus are presented in Table 4. The growth rates of fish in D1 and D2 treatments were significantly higher $(p<0.05)$ than in the D3 treatment. The mean weight gain followed a similar trend to that of the growth rates. The feed conversion ratio and survival rate were comparable $(p>0.05)$ in all the treatments.

Table 4. Fish growth parameters in the three aquaponic systems during the study period. All values are mean \pm standard deviation obtained from three replicates. Different superscript letters $(a, b)$ within a row indicate statistically different mean values at $p<0.05 ; \mathrm{a}>\mathrm{b}>\mathrm{c}$ (one-way ANOVA).

\begin{tabular}{ccccc}
\hline Parameters & Units & D1 & D2 & D3 \\
\hline Weight gain & $(\mathrm{g})$ & $21.6 \pm 1.57^{\mathrm{a}}$ & $19.2 \pm 2.38^{\mathrm{a}}$ & $12.9 \pm 3.15^{\mathrm{b}}$ \\
Specific growth rate & $(\%)$ & $0.35 \pm 0.03^{\mathrm{a}}$ & $0.32 \pm 0.02^{\mathrm{a}}$ & $0.22 \pm 0.04^{\mathrm{b}}$ \\
Feed conversion ratio & & $1.9 \pm 0.20^{\mathrm{a}}$ & $2.0 \pm 0.25^{\mathrm{a}}$ & $2.3 \pm 0.20^{\mathrm{a}}$ \\
Survival rate & $(\%)$ & $96.7 \pm 3.06^{\mathrm{a}}$ & $98.0 \pm 3.46^{\mathrm{a}}$ & $95.3 \pm 6.43^{\mathrm{a}}$ \\
\hline a, b within a row indicate statistically different mean values at $p<0.05 \cdot \mathrm{a}>\mathrm{b}>\mathrm{c}$ (one-way ANOVA)
\end{tabular}

${ }^{\mathrm{a}, \mathrm{b}}$ within a row indicate statistically different mean values at $p<0.05 ; \mathrm{a}>\mathrm{b}>\mathrm{c}$ (one-way ANOVA).

\section{Discussion}

Aquaponic systems were designed to provide optimal water quality for the growth of fish. In these systems, plants absorb nutrients excreted by fish and hence maintain suitable water conditions for the growth of fish [35]. In this study, water quality parameters were within recommended limits for the culture of $O$. niloticus in fish tanks except for ammonia and dissolved oxygen. The high ammonia levels may be attributed to high $\mathrm{pH}$ levels (7.97) that favored the evolution of ammonia in the culture water. The relative proportion of unionized ammonia $\left(\mathrm{NH}_{3}\right)$ and ammonium ion $\left(\mathrm{NH}_{4}{ }^{+}\right)$in the culture water is mainly influenced by $\mathrm{pH}$ [36]. The unionized ammonia dominates when the $\mathrm{pH}$ is high whereas ammonium ion dominates when the $\mathrm{pH}$ is low. But when the $\mathrm{pH}$ is $<8.0$, less than $10 \%$ of evolved ammonia is toxic [36]. The $\mathrm{pH}$ in this study was less than 8.0 indicating that the proportion of toxic ammonia in the culture water was low. Mean dissolved oxygen was lower than recommended ( $5 \mathrm{mg} / \mathrm{L})$, but the Nile tilapia can tolerate oxygen concentrations as low as $1.0 \mathrm{mg} / \mathrm{L}$ [37]. However, the low dissolved oxygen levels below $3.5 \mathrm{mg} / \mathrm{L}$ affect growth and feed conversion [38].

Mean water temperature and conductivity in this study was similar to values observed in other aquaponic systems [39,40]. Dissolved oxygen (DO) levels were lower than 6.3-7.7 mg/L reported by [40] in an ebb and flood aquaponic system. The low DO levels could be attributed to the chemical transformation processes in the aquaponic system including fish respiration, production of high organic loads in the aquaponic system, activities of heterotrophs in addition to oxidation of nitrifying bacteria and oxygen absorption by plant roots [41,42]. Therefore, high DO levels should be maintained in these aquaponic systems for optimal plant growth. Besides, hydroponic plants absorb large amounts of oxygen from the culture water because of their intense root respiration. However, root respiration decreases in low DO conditions causing a reduction in water and nutrient absorption as well as plant growth [43]. 
$\mathrm{pH}$ is a key factor for plant growth because it can limit but not inhibit the availability of nutrients such as boron, zinc, copper, manganese, and iron. The $\mathrm{pH}$ can as well affect the absorption of phosphorus, magnesium, molybdenum and calcium and plant development [39]. Therefore, $\mathrm{pH}$ levels should be maintained between 5.5 and 6.5 to achieve optimum nutrient absorption and plant growth [42]. $\mathrm{pH}$ levels in this study were higher than 5.5 and 6.5 but slightly above the recommended level (7.0) for recirculating aquaponic water. Thus, the $\mathrm{pH}$ levels may have probably influenced the nutrient availability and plant biomass because plant production reduces at relatively high $\mathrm{pH}$ levels [44]. Potassium hydroxide or calcium hydroxide can be added in the aquaponic systems to stabilize $\mathrm{pH}$ [23]. However, most aquaponic systems maintain a slightly alkaline medium between 6.5 and $9.0[45]$.

Nutrient uptake by plants contributes significantly to the removal of nutrients from aquaponic systems [23]. However, the nutrient removal capacity of aquaponic plants is influenced by (1) the growth stage and nutrient needs of the plant and (2) the activity of ammonia-oxidizing bacteria in the aquaponic system [41,46]. Young plants have low nutrient requirements, but this increases during the vegetative growth [47]. Moreover, aquaponic plant roots provide a surface area for the attachment of microbial organisms that oxidize toxic ammonia to nitrates [48]. Therefore, low ammonia, nitrate and nitrite removal at the beginning of the experiment can be attributed to the nutrient needs of the plants as well as the young roots which could not provide a large surface area for the attachment of nitrifiers. At the end of the experiment, the concentration of the nutrients decreased because the plant roots had fully developed. The fully developed roots provided a large surface area for bacteria responsible for nitrification resulting in significantly low ammonia concentrations at the end of the experiment. Similar findings were reported in an aquaponics system for catfish (Clarias gariepinus), water spinach (Ipomoea aquatica) and mustard green (Brassica juncea) production [48].

The activity of the nitrifying bacteria can explain the ammonia, nitrate and nitrite trend in the aquaponic system. The nitrifiers play a significant role in the removal of nitrogen in media-based aquaponic systems [14,41]. The nitrifying bacteria are naturally slow growing and can take a long period to establish and multiply [49]. Therefore, the high nutrient concentration at week 2 might indicate that the nitrifiers had not established properly resulting in a low nitrification rate. The low ammonia levels at week 8 might be attributed to high ammonia oxidation rates after the proper establishment of nitrifying bacteria. The concentration of phosphorus at week 2 was low due to increased demand for root development because the plants were still young. Moreover, young plants engage in luxury uptake of phosphorus to counterbalance an anticipated phosphorus need at a later stage [46].

Lower nutrient concentrations were obtained in aquaponic systems with plants than in the control system. The aquaponic system with plants was effective in removal of nutrients because the plants absorbed more wastes generated from the recirculating aquaculture system. The removal of nutrients in the high density system might be attributed to a large planted area which provided a large surface area for the establishment of microbial organisms responsible for nitrogen removal [50]. The results showed that the aquaponic system without plants removed a proportion of nutrients from the effluent water, indicating that other processes apart from plant uptake contributed to the removal of nitrogen in the aquaponic system. Microbial processes in the plant root zone play a major role in the removal of nutrients in gravel-based aquaponic systems [9]. This implies that the actual plant uptake of nutrients might not have contributed significantly to the overall nutrient removal.

Plant roots provide a large surface area for attachment of nitrifying and denitrifying bacteria that convert toxic ammonia to non-toxic nitrogen compounds [45]. Nitrification occurs in aerobic conditions near the roots and on the surface of the roots while denitrification occurs in anoxic zones [9]. In [9], plants utilized only $6 \%$ and $7 \%$ of nitrogen and phosphorus respectively whereas $45 \% \mathrm{~N}$ and $9 \%$ $\mathrm{P}$ was unaccounted for in the nutrient balance, suggesting that the unaccounted $\mathrm{N}$ and $\mathrm{P}$ was probably bound in the biofilms of the gravel substrate and lost through denitrification. Anoxic conditions that generally develop in media-based aquaponics provide a suitable environment for denitrification 
which removes a substantial amount of nitrogen from the system [9]. Therefore, the removal of nitrogen through nitrification and denitrification processes is perhaps underestimated and nitrogen removal through plant assimilation overestimated in most aquaponic systems [9,14]. The removal of phosphorus was not as efficient as nitrogen removal because phosphorus might have been released under anaerobic conditions. Fine solid accumulation as well as lack of flow and circulation in media based aquaponic systems normally create anaerobic pockets [51]. Under anaerobic conditions, low molecular organic compounds are converted to polyhydroxyalkanoates (PHA), poly-P and glycogen are degraded, and phosphorus is released [13]. Phosphate accumulation due to degradation of organic $P$ was also reported [9] but on the contrary another study by [52] showed a declining trend in phosphorus concentration throughout the study period.

In this study, plant density did not affect the relative growth rate of $A$. annua in the aquaponic systems. Similarly, previous aquaponic studies showed that halophyte [14] and barley plant densities [53] did not impact the growth rate. However, [22] reported decreased plant growth in high plant densities. The final weight and yield of the plants were better in the D1 treatment due to high densities compared to the low plant density treatment. Our findings correspond to other previous aquaponic studies $[53,54]$ that reported significantly high plant biomass and yield at high plant density aquaponic systems. However, a further increase in plant density can decrease plant production [22]. Therefore, there is need for optimum plant density to efficiently utilize nutrients and optimize yield in aquaponic systems. No nutrient deficiencies were observed in the high plant densities ( 48 plants $/ \mathrm{m}^{2}$ ) in this study. This suggests that $A$. annua can be grown at higher plant densities than the 48 plants $/ \mathrm{m}^{2}$ under the investigated conditions. Our findings suggest that wastes from a recirculating aquaculture system can support the growth of $A$. annua.

Fish in high and low plant density systems performed better than in control system that was without plants. The performance of fish might be attributed to the ability of the plants to remove wastes from the aquaponic system and maintain good water quality in the fish rearing tanks. The results suggest that the growth of fish was influenced by water quality in the culture tanks. This study used similar initial weights as other studies have done but the specific growth rates of O. niloticus were lower than $0.7 \%$ and $2.5 \%$ reported in previous aquaponic studies $[45,55]$. The FCR values in all the treatments were slightly higher than the recommended 1.5-2 for intensively cultured tilapia [56]. Water quality parameters particularly ammonia concentrations above $1.0 \mathrm{mg} / \mathrm{L}$ might have influenced the feed intake resulting in poor FCR and lower growth rates [38]. Another study demonstrated that the growth performance of $O$. niloticus decreases and FCR increases as the concentration of ammonia increases [57]. The multiple regression analysis confirmed that water quality parameters had a significant influence on the growth of fish. However, studies have shown that accumulation of other substances including heavy metals [58], dissolved carbon dioxide [59], pheromones, cortisol [60] and steroids [61] can significantly affect the growth of fish in recirculating aquaculture systems. A study by Mota et al. [61] reported a $42 \%$ and $83 \%$ reduction in feed intake and growth respectively in O. niloticus cultured recirculating systems with minimal water exchange rates. The minimal water exchange (weekly) during the study period probably influenced the ammonia levels and the growth of fish. However, the survival rate was $>95 \%$ in all the treatments demonstrating the suitability of Nile tilapia for aquaponic systems [45].

Several studies have shown that a wide variety of plants can be successfully grown in aquaponic systems. However, the aim is to culture valuable plants that can generate high income per unit area and time [62]. Our findings indicate that $A$. annua is one of the plants that can be grown in aquaponic systems because of its nitrogen removal capabilities and its high economic value as a medicinal plant. Artemisia annua is the only source of artemisinin, a well-established and widely used antimalarial compound [28]. Besides, the plant has diverse medicinal uses including aromatherapy, boosting the immune system, antioxidant and anti-inflammatory properties and has antimicrobial capabilities against diverse pathogens [63]. Therefore, farmers and investors can increase their income from the production of fish and valuable $A$. annua. 


\section{Conclusion}

The objective of this study was to evaluate the effect of plant density on nutrient removal capacity by using $A$. annua in an aquaponic system. The findings indicate that a high plant density system contributed significantly to the removal of nutrients from the aquaponic system. The system with no plants contributed to the removal of nutrients suggesting that other mechanisms such as nitrification and denitrification can be responsible for nutrient removal. Plant density did not have an impact on the relative growth rate of $A$. annua but influenced its productivity and the performance of $O$. niloticus. This finding indicates that the aquaponic system can sustain higher plant densities than 48 plants $/ \mathrm{m}^{2}$. This study demonstrates that $A$. аnnиa can significantly reduce nitrogen in aquaculture wastes making it a potential plant species for inclusion in aquaponic systems. However, further research is needed to evaluate the growth and nitrogen removal capacity of $A$. annua using different growth substrates and/or hydroponic systems. Further studies should also investigate the nutritional content and meat quality of fish grown in the aquaponic systems.

Author Contributions: Conceptualization, Z.G.; D.L.; W.Z., and H.W.; methodology, Z.G.; D.L.; W.Z.; H.W.; P.M.; S.D. and E.O.; investigation, Z.G.; formal analysis, Z.G.; D.L.; W.Z.; H.W.; P.M.; S.D. and E.O.; writing-original draft preparation, Z.G.; writing-reviewing and editing, Z.G.; D.L.; H.W.; P.M.; S.D. and E.O.; supervision, D.L.; W.Z.; H.W.; P.M. and S.D.; project administration, P.A.; funding acquisition, P.A.

Funding: This research was funded by the Austrian Partnership Programme in Higher Education and Research for Development-APPEAR, a programme of the Austrian Development Cooperation (ADC) and implemented by the Austrian Agency for International Cooperation in Education and Research (OeAD).

Acknowledgments: The authors thank E. Lautsch for his support in data analysis. Special thanks to the APPEAR project "Strengthening Regional Capacity in Research and Training in Fisheries and Aquaculture for Improved Food Security and Livelihoods in Eastern Africa" (STRECAFISH), Department of Biological Sciences, University of Eldoret (UoE) for logistical support, Aqualife fish farm, R. Magoma and B. Sunda for technical support during the study.

Conflicts of Interest: The authors declare no conflict of interest.

Ethical Statement: The study was carried out in accordance with the international, national and institutional guidelines for the care of experimental animals.

\section{References}

1. FAO. The State of the World Fisheries and Aquaculture 2018. Meeting the Sustainable Development Goals; Food and Agriculture Organization of the United Nations: Rome, Italy, 2018; p. 194.

2. Waite, R.; Beveridge, M.; Brummett, R.; Castine, S.; Chaiyawannakarn, N.; Kaushik, S.; Mungkung, R.; Nawapakpilai, S.; Phillips, M. Improving productivity and environmental performance of aquaculture. Create. Sustain. Food Future 2014, 1-60.

3. FAO. The State of World Fisheries and Aquaculture 2016. Contributing to Food Security and Nutrition for All; Food and Agricultural Organization of the United Nations: Rome, Italy, 2016; p. 204.

4. Verdegem, M.C.J.; Bosma, R.H.; Verreth, J.A.J. Reducing Water Use for Animal Production through Aquaculture. Int. J. Water Resour. Dev. 2006, 22, 101-103. [CrossRef]

5. Opiyo, M.A.; Marijanib, E.; Muendoc, P.; Odede, R.; Leschen, W.; Charo-Karisa, H. A review of aquaculture production and health management practices of farmed fish in Kenya. Int. J. Vet. Sci. Med. 2018, 6, 141-148. [CrossRef] [PubMed]

6. Funge-Smith, S.; Philips, M.J. Aquaculture systems and species. In Proceedings of the Aquaculture in the Third Millennium; NACA: Bangkok, Thailand; FAO: Rome, Italy, 2001; pp. 129-135.

7. Trang, N.; Schierup, H.-H.; Brix, H. Leaf vegetables for use in integrated hydroponics and aquaculture systems: Effects of root flooding on growth, mineral composition and nutrient uptake. Afr. J. Biotechnol. 2010, 9, 4186-4196.

8. Okomoda, V.T.; Tiamiyu, L.O.; Iortim, M. The effect of water renewal on growth of Clarias gariepinus fingerlings. Croat. J. Fish. 2016, 74, 25-29. [CrossRef]

9. Trang, N.T.D.; Brix, H. Use of planted biofilters in integrated recirculating aquaculture-hydroponics systems in the Mekong Delta, Vietnam. Aquac. Res. 2014, 45, 460-469. [CrossRef] 
10. Silva, L.; Valdés-Lozano, D.; Escalante, E.; Gasca-Leyva, E. Dynamic root floating technique: An option to reduce electric power consumption in aquaponic systems. J. Clean. Prod. 2018, 183, 132-142. [CrossRef]

11. Badiola, M.; Mendiola, D.; Bostock, J. Recirculating Aquaculture Systems (RAS) Analysis: Main Issues on Management and Future Challenges. Aquac. Eng. 2012, 51, 21-35.

12. Piedrahita, R.H. Reducing the potential environmental impact of tank aquaculture effluents through intensification and recirculation. Aquaculture 2003, 226, 35-44. [CrossRef]

13. Van Rijn, J.; Tal, Y.; Schreier, H.J. Denitrification in recirculating systems: Theory and applications. Aquac. Eng. 2006, 34, 364-376. [CrossRef]

14. Boxman, S.E.; Nystrom, M.; Capodice, J.C.; Main, K.L.; Trotz, M.A. Effect of support medium, hydraulic loading rate and plant density on water quality and growth of halophytes in marine aquaponic systems. Aquac. Res. 2017, 48, 2463-2477. [CrossRef]

15. Eck, M.; Sare, A.R.; Massart, S.; Schmautz, Z.; Junge, R.; Smits, T.H.M.; Jijakli, M.H. Exploring Bacterial Communities in Aquaponic Systems. Water 2019, 11, 260. [CrossRef]

16. Bartelme, R.P.; Oyserman, B.O.; Sepulveda-Villet, O.J.; Newton, R.J. Stripping Away the Soil: Plant Growth Promoting Microbiology Opportunities in Aquaponics. Front. Microbiol. 2018, 9. [CrossRef] [PubMed]

17. Stathopoulou, P.; Berillis, P.; Levizou, E.; Sakellariou-Makrantonaki, M.; Kormas, A.K.; Aggelaki, A.; Kapsis, P.; Vlahos, N.; Mente, E. Aquaponics: A mutually beneficial relationship of fish, plants and bacteria. In Proceedings of the 3rd International Congress on Applied Ichthyology \& Aquatic Environment, Volos, Greece, 8-11 November 2018.

18. Goddek, S.; Espinal, C.A.; Delaide, B.; Jijakli, M.H.; Schmautz, Z.; Wuertz, S.; Keesman, K.J. Navigating towards decoupled aquaponic systems: A system dynamics design approach. Water 2016, 8, 303. [CrossRef]

19. Gichana, Z.M.; Liti, D.; Waidbacher, H.; Zollitsch, W.; Drexler, S.; Waikibia, J. Waste management in recirculating aquaculture system through bacteria dissimilation and plant assimilation. Aquac. Int. 2018, 26, 1541-1572. [CrossRef]

20. FAO. FAO Technical Workshop on Advancing Aquaponics: An Efficient Use of Limited Resources. Saint John's, Antigua and Barbuda, 14-18 August 2017; FAO Fisheries and Aquaculture Report. No. 1214; FAO Subregional Office for the Caribbean: Bridgetown, Barbados, 2017.

21. Goddek, S.; Delaide, B.; Mankasingh, U.; Ragnarsdottir, K.V.; Jijakli, H.; Thorarinsdottir, R. Challenges of sustainable and commercial aquaponics. Sustainability 2015, 7, 4199-4224. [CrossRef]

22. Endut, A.; Jusoh, A.; Ali, N.; Wan Nik, W.B.; Hassan, A. A study on the optimal hydraulic loading rate and plant ratios in recirculation aquaponic system. Bioresour. Technol. 2010, 101, 1511-1517. [CrossRef]

23. Rakocy, J.E. Integrating fish and plant culture. In Aquaculture Production Systems; John Wiley \& Sons, Inc.: Oxford, UK, 2012.

24. Lam, S.S.; Ma, N.L.; Jusoh, A.; Ambak, M.A. Biological nutrient removal by recirculating aquaponic system: Optimization of the dimension ratio between the hydroponic \& rearing tank components. Int. Biodeterior. Biodegrad. 2015, 102, 107-115.

25. Maboko, M.; Du Plooy, C. Effects of plant spacing and harvesting frequency on the yield of Swiss chard cultivars (Beta vulgaris L.) in a closed hydroponic system. Afr. J. Agric. Res. 2013, 8, 936-942.

26. Søberg, E.-E. The Growth and Development of Lettuce, Coriander and Swiss Chard in a Cold Water Aquaponic System Optimized for Lettuce Production. Master's Thesis, Norwegian University of Life Sciences, Oslo, Norway, 2016.

27. Pulice, G.; Pelaz, S.; Matías-Hernández, L. Molecular Farming in Artemisia annua, a Promising Approach to Improve Anti-malarial Drug Production. Front. Plant. Sci. 2016, 7. [CrossRef] [PubMed]

28. Ferreira, J.F.S. Nutrient Deficiency in the Production of Artemisinin, Dihydroartemisinic Acid, and Artemisinic Acid in Artemisia annua L. J. Agric. Food Chem. 2007, 55, 1686-1694. [CrossRef]

29. WHO. WHO Monograph on Good Agricultural and Collection Practices (GACP) for Artemisia annua L.; World Health Organization: Geneva, Switzerland, 2006; p. 49.

30. Namuli, A.; Bazira, J.; Casim, T.U.; Engeu, P.O. A review of various efforts to increase artemisinin and other antimalarial compounds in Artemisia Annua L plant. Cog. Biol. 2018, 4, 1-8. [CrossRef]

31. Delong, D.P.; Losordo, T.M. How to start a Biofilter. SRAC Publ. South. Reg. Aquac. Cent. 2012, 3, 1-4.

32. Bruno, R.; Chen, W.; Cottle, P.; Lai, V.; Loc, H.; Delson, N. Aquaponics Ebb and Flow Mechanisms ECOLIFE Foundation. MAE 156B: Fundamental Principles of Mechanical Design II; University of California: Oakland, CA, USA, 2011; p. 85. 
33. American Public Health Association (APHA). Standard Method for the Examination of Water and Wastewater; Water Pollution Control Federation: Baltimore, MD, USA, 2008.

34. Tylova-Munzarova, E.; Lorenzen, B.; Brix, H.; Votrubova, O. The effects of $\mathrm{NH}_{4}{ }^{+}$and $\mathrm{NO}_{3}{ }^{-}$on growth, resource allocation and nitrogen uptake kinetics of Phragmites australis and Glyceria maxima. Aquat. Bot. 2005, 81, 326-342. [CrossRef]

35. Ngo Thuy Diem, T.; Konnerup, D.; Brix, H. Effects of recirculation rates on water quality and Oreochromis niloticus growth in aquaponic systems. Aquac. Eng. 2017, 78, 95-104. [CrossRef]

36. Hargreaves, J.A.; Tucker, C.S. Managing ammonia in fish pond. SRAC Publ. South. Reg. Aquac. Cent. 2004, 8. Available online: http:/fisheries.tamu.edu/files/2013/09/SRAC-Publication-No.-4603-Managing-Ammoniain-Fish-Ponds.pdf (accessed on 2 March 2019).

37. Ross, L. Environmental physiology and energetics. In Tilapias: Biology and exploitation; Springer: Dordrecht, The Netherlands, 2000; pp. 89-128.

38. Delong, D.P.; Losordo, T.M.; Rakocy, J.E. Tank Culture of Tilapia; Southern Regional Aquaculture Center: toneville, MS, USA, 2009.

39. Knaus, U.; Palm, H.W. Effects of the fish species choice on vegetables in aquaponics under spring-summer conditions in northern Germany (Mecklenburg Western Pomerania). Aquaculture 2017, 473, 62-73. [CrossRef]

40. Pinho, S.M.; de Mello, G.L.; Fitzsimmons, K.M.; Emerenciano, M.G.C. Integrated production of fish (pacu Piaractus mesopotamicus and red tilapia Oreochromis sp.) with two varieties of garnish (scallion and parsley) in aquaponics system. Aquac. Int. 2018, 26, 99-112. [CrossRef]

41. Wongkiew, S.; Hu, Z.; Chandran, K.; Lee, J.W.; Khanal, S.K. Nitrogen transformations in aquaponic systems: A review. Aquac. Eng 2017, 76, 9-19. [CrossRef]

42. Espinosa-Moya, A.; Álvarez-gonzález, A.; Albertos-alpuche, P. Growth and development of herbaceous plants in aquaponic systems. Acta Univ. Multidisp. Sci. J. 2018, 28, 1-8.

43. Masser, M.P.; Rakocy, J.; Losordo, T.M. Recirculating Aquaculture Tank Production Systems Management of Recirculating Systems. South. Reg. Aquac. Cent. 1992, 1-12. Available online: https://www.academia.edu/26860809/Southern_Regional_Aquaculture_Center_Recirculating_Aquaculture_ Tank_Production_Systems_Management_of_Recirculating_Systems. (accessed on 22 January 2019).

44. Pinho, S.M.; Molinari, D.; de Mello, G.L.; Fitzsimmons, K.M.; Coelho Emerenciano, M.G. Effluent from a biofloc technology (BFT) tilapia culture on the aquaponics production of different lettuce varieties. Ecol. Eng. 2017, 103, 146-153. [CrossRef]

45. Estim, A.; Saufie, S.; Mustafa, S. Water quality remediation using aquaponics sub-systems as biological and mechanical filters in aquaculture. J. Water Process. Eng. 2018. [CrossRef]

46. Buzby, K.M.; Lin, L.S. Scaling aquaponic systems: Balancing plant uptake with fish output. Aquac. Eng. 2014, 63, 39-44. [CrossRef]

47. Jones, C.; Olson-rutz, K.; Dinkins, C. Nutrient Uptake Timing by Crops, to Assist with Fertilizing Decisions; Montana State University: Bozeman, MT, USA, 2015; p. 8.

48. Endut, A.; Lananan, F.; Jusoh, A.; Cik, W.N.W.; Nora'aini, A. Aquaponics Recirculation System: A Sustainable Food Source for the Future Water Conserves and Resources. Malays. J. Appl. Sci. 2016, 1, 1-12.

49. Timmons, M.B.; Ebeling, J.M.; Wheaton, F.W.; Summerfelt, S.T.; Vinci, B.J. Recirculating Aquaculture Systems, 2nd ed.; Cayuga Aqua Ventures Llc: New York, NY, USA, 2002.

50. Webb, J.M.; Quintã, R.; Papadimitriou, S.; Rigby, N.L.; Norman, M.; Thomas, D.N.; Le Vay, L. The effect of halophyte planting density on the efficiency of constructed wetlands for the treatment of wastewater from marine aquaculture. Ecol. Eng. 2013, 61, 145-153. [CrossRef]

51. Thorarinsdottir, R.I. Aquaponics Guidelines. In Lifelong learning Programme; European Commission: Reykjavik, Iceland, 2015; p. 69.

52. Cerozi, B.S.; Fitzsimmons, K. Phosphorus dynamics modeling and mass balance in an aquaponics system. Agric. Syst. 2017, 153, 94-100. [CrossRef]

53. Snow, A.M.; Ghaly, A.E. A Comparative Study of the Purification of Aquaculture Wastewater Using Water Hyacinth, Water Lettuce and Parrot's Feather. Am. J. Appl. Sci. 2008, 5, 440-453.

54. Endut, A.; Jusoh, A.; Ali, N.; Wan Nik, W.B. Nutrient removal from aquaculture wastewater by vegetable production in aquaponics recirculation system. Desalin. Water Treat. 2011, 32, 422-430. [CrossRef] 
55. Silva, L.; Escalante, E.; Valdés-Lozano, D.; Hernández, M.; Gasca-Leyva, E. Evaluation of a semi-intensive aquaponics system, with and without bacterial biofilter in a tropical location. Sustainability 2017, 9, 592. [CrossRef]

56. Stickney, R.R. Aquaculture: an introduction text; CABI Publication: Cambridge, MA, USA, 2005.

57. El-Sherif, M.S.; El-Feky, A.M. Effect of Ammonia on Nile Tilapia (O. niloticus) Performance and some Hematological and Histological Measures. In Proceedings of the 8th International Symposium on Tilapia in Aquaculture, Cairo, Egypt, 12-14 October 2008; pp. 513-530.

58. Davidson, J.; Good, C.; Welsh, C.; Brazil, B.; Summerfelt, S. Heavy metal and waste metabolite accumulation and their potential effect on rainbow trout performance in a replicated water reuse system operated at low or high flushing rates. Aquac. Eng. 2009, 41, 136-145. [CrossRef]

59. Colt, J. Water quality requirements for reuse systems. Aquac. Eng. 2006, 34, 143-156. [CrossRef]

60. Martins, C.I.M.; Ochola, D.; Ende, S.S.W.; Eding, E.H.; Verreth, J.A.J. Is growth retardation present in Nile tilapia Oreochromis niloticus cultured in low water exchange recirculating aquaculture systems? Aquaculture 2009, 298, 43-50. [CrossRef]

61. Mota, V.C.; Limbua, P.; Martins, C.I.M.; Eding, E.; Verreth, A.J. The effect of nearly closed RAS on the feed intake and growth of Nile tilapia (Oreochromis niloticus), African catfish (Clarias gariepinus) and European eel (Anguilla anguilla). Aquac. Eng. 2015, 68,1-5. [CrossRef]

62. Bakiu, R.; Shehu, J. Aquaponic systems as excellent agricultural research instruments in Abania. Albanian J. Agric. Sci 2014, 2014.

63. Kim, W.S.; Choi, W.J.; Lee, S.; Kim, W.J.; Lee, D.C.; Sohn, U.D.; Shin, H.S.; Kim, W. Anti-inflammatory, Antioxidant and Antimicrobial Effects of Artemisinin Extracts from Artemisia annua L. Korean J. Physiol. Pharmacol. 2015, 19, 21-27. [CrossRef] [PubMed]

(C) 2019 by the authors. Licensee MDPI, Basel, Switzerland. This article is an open access article distributed under the terms and conditions of the Creative Commons Attribution (CC BY) license (http://creativecommons.org/licenses/by/4.0/). 